\title{
Exergy and Environmental Impact Assessment between Solar Powered Gas Turbine and Conventional Gas Turbine Power Plant
}

\author{
Ali Rajaei, ${ }^{1}$ Hasan Barzegar Avval, ${ }^{2}$ and Elmira Eslami ${ }^{1}$ \\ ${ }^{1}$ Power and Water University of Technology, Tehran, Iran \\ ${ }^{2}$ Energy Optimization Research and Development Group (EORDG), Tehran, Iran \\ Correspondence should be addressed to Ali Rajaei; alirajaee110@gmail.com
}

Received 17 December 2015; Revised 12 April 2016; Accepted 14 April 2016

Academic Editor: Halil S. Hamut

Copyright (C) 2016 Ali Rajaei et al. This is an open access article distributed under the Creative Commons Attribution License, which permits unrestricted use, distribution, and reproduction in any medium, provided the original work is properly cited.

\begin{abstract}
Recuperator is a heat exchanger that is used in gas turbine power plants to recover energy from outlet hot gases to heat up the air entering the combustion chamber. Similarly, the combustion chamber inlet air can be heated up to temperatures up to $1000\left({ }^{\circ} \mathrm{C}\right.$ ) by solar power tower (SPT) as a renewable and environmentally benign energy source. In this study, comprehensive comparison between these two systems in terms of energy, exergy, and environmental impacts is carried out. Thermodynamic simulation of both cycles is conducted using a developed program in MATLAB environment. Exergetic performances of both cycles and their emissions are compared and parametric study is carried out. A new parameter (renewable factor) is proposed to evaluate resources quality and measure how green an exergy loss or destruction or a system as a whole is. Nonrenewable exergy destruction and loss are reduced compared to GT with recuperator cycle by $34.89 \%$ and $47.41 \%$, respectively. Reductions in $\mathrm{CO}_{2}, \mathrm{NO}_{x}$, and $\mathrm{CO}$ compared to GT with recuperator cycle by $49.92 \%, 66.14 \%$, and $39.77 \%$, respectively, are in line with renewable factor value of around 55.7 which proves the ability of the proposed green measure to evaluate and compare the cycles performances.
\end{abstract}

\section{Introduction}

Recuperation as one of the conventional optimization enhancements in gas turbine cycles by preheating inlet air entering combustor which decreases fuel consumption rate dramatically leads to less greenhouse gas emissions. The other way refers to hybridizing gas cycle with solar power. Advantages of combining solar thermal power with power generation systems are reviewed by Jamel et al. [1]. Renewable sources integration with power cycles with the aim of increasing total exergy efficiency based on different scenarios is performed by them.

Several studies are conducted on energy and exergy analysis of hybrid solar gas cycles [2]. Solar power tower as a central receiver system recently has been built in both demonstrational and commercial projects all over the world [3]. Schwarzbözl et al. [4] using advanced software tools carried out design optimization and performance prediction of the solar tower gas turbine power plants. Their project proved feasibility of solar tower integration with conventional gas turbine power plant. It is proved that hybrid solar gas turbine cycles are more efficient in terms of $\mathrm{CO}_{2}$ emission prevention compared to conventional gas cycle with recuperator.

Comparing energy systems often is performed through measuring environmental characteristics and performance in terms of energy and exergy analysis [2]. Thermodynamic modeling, second-law based thermodynamic analysis, and multiobjective optimization of a gas turbine power plant with and without recuperator are conducted $[5,6]$.

In this paper, two scenarios are defined based on different heat sources to preheat the air inlet to combustor. First is a conventional gas turbine cycle with recuperator and the second is a solar power tower coupled with a gas turbine where central receiver plays the same role as the recuperator. In order to find inefficiencies in both cycles, exergy analysis is performed by simulating the cycles using MATLAB program. 
Exergoenvironmental analysis tool by predicting emissions rate helps designing a more sustainable cycle. Environmental impacts including $\mathrm{CO}_{2}, \mathrm{NO}_{x}$, and $\mathrm{CO}$ are measured through the developed code. $\mathrm{SO}_{x}$ which is prevented by preoperations in all gas cycles is considered negligible in modeling.

This analysis is aimed at quantitatively addressing the impact of renewable and nonrenewable sources on environment by introducing renewable factor. In research studies to the authors' knowledge, all sources are considered the same. Losses and destructions from various sources are equivalent in common exergy analysis. However, losses and destructions from renewable resources are different from nonrenewable resources since all exergy flows have impacts on environment. In the present work, a new measure is introduced and renewable and nonrenewable loss and destructions are calculated to show the real effect of using renewable resources in environmental impacts reduction.

The Present study highlights exergy and exergoenvironmental analysis of both mentioned cycles by measuring their exergy destructions throughout the cycle and comparing their total exergy efficiencies in order to reach a better insight:

(i) To model a new arrangement of new hybrid gas cycle.

(ii) To conduct exergy and exergoenvironmental analysis in order to find inefficiencies.

(iii) To propose renewable factor which helps in comparing renewable and nonrenewable sources quantitatively and more accurately.

\section{System Description and Assumptions}

In this research paper, two scenarios are presented. The first one includes heliostat solar field, central receiver, and power generation system while the second one comprises a recuperator instead of prime solar system.

Figure 1(a) demonstrates SPT cycle designed similarly based on SOLGATE project cycle [4] in which the solar hybrid gas turbine system functions by first concentrating solar energy from a heliostat field (solar field) to a receiver mounted on top of a tower acting as a convective/radiative heat exchanger. These irradiations are converted into heat absorbed by the air coming from compressor. Preheated air enters combustor in order to be mixed with the fuel where the combustion chamber closes the temperature gap between the receiver outlet temperature $\left(800-1000^{\circ} \mathrm{C}\right.$ at design point) and the turbine inlet temperature $\left(950-1300^{\circ} \mathrm{C}\right)$ and provides constant turbine inlet conditions despite fluctuating solar input. The solar power tower technology is used with concentration ratios up to 1000 suns to achieve the high receiver temperatures. More detailed information about the receiver development and test results with receiver temperatures up to $960^{\circ} \mathrm{C}$ can be found in [7].

To model and compare two cycles, thermodynamic modeling of both systems is carried out. Systems are analyzed at their design point using provided data and average yearly DNI for solar system. Then exergy analysis and emission calculations are carried out and systems' performances are compared.
In the second scenario recuperator is used as a replacement of mentioned solar part in first cycle. Several assumptions are made in order to render the analyses in a traceable way considered to model the cycles in the present study which are listed below:

(1) All the processes are assumed to work under steadystate condition.

(2) Combustion products and air stream are considered ideal gas.

(3) Natural gas enters combustor as fuel.

(4) Dead state is $P_{0}=1.01$ bar and $T_{0}=293.15 \mathrm{~K}$.

\section{Formulation}

The present study performed exergy and exergoenvironmental analysis both on each cycle where in the first one solar receiver, as external source, and in the second one recuperator, as internal source, are considered.

3.1. Recuperator. The energy balance equation for recuperator which is shown in Figure 1 is as follows:

$$
\dot{m}_{\text {air }}\left(h_{3}-h_{2}\right)=\dot{m}\left(h_{5}-h_{6}\right) \eta_{\text {recup }}
$$

Recuperator efficiency is usually $95-97 \%$ and in many cases is considered $100 \%$. Here $97 \%$ percent is assumed based on an average value in similar GT cycles [5]:

$$
\frac{P_{3}}{P_{2}}=\left(1-\Delta P_{\text {recup }}\right) \text {, }
$$

where pressure drop through the recuperator is considered $3 \%$ of the inlet pressure for both flow streams and through the combustion chamber is 3\% of the inlet pressure [5].

3.2. Solar System. As shown in Figure 1, central receiver has two input streams, solar irradiations and compressed air which gets warmer by absorbing the heat coming from solar rays. In this analysis $\dot{Q}$ is the transferred heat rate as

$$
\dot{Q}=\frac{H_{\text {out }}-H_{\text {in }}}{\eta_{\text {rec }}},
$$

where $H_{\text {out }}$ and $H_{\text {in }}$ are outlet and inlet stream enthalpy:

$$
\begin{gathered}
\dot{Q}_{\text {rec }}=\dot{Q} * \dot{m}_{\text {air }}, \\
\text { Solar share }=\frac{\dot{Q}_{\text {rec }}}{\dot{m}_{F} * \mathrm{LHV}+\dot{Q}_{\text {rec }}} .
\end{gathered}
$$

Solar share shows renewable heat source contribution into conventional fossil fuel cycles and is defined as below:

$$
\text { Solar share }=\frac{\dot{Q}_{\text {rec }}}{\dot{Q}_{\text {natural gas }}+\dot{Q}_{\text {rec }}} * 100,
$$

where $\dot{\mathrm{Q}}_{\text {natural gas }}$ is the supplied heat by fuel:

$$
\dot{Q}_{\text {natural gas }}=\dot{m}_{F} \mathrm{LHV} \text {. }
$$




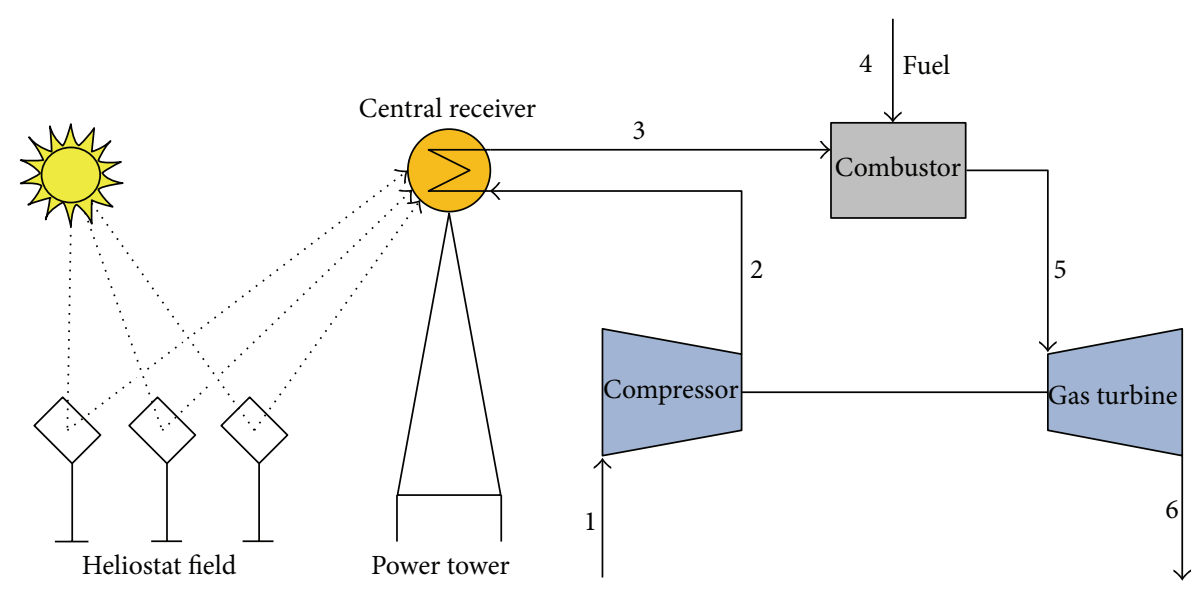

(a)

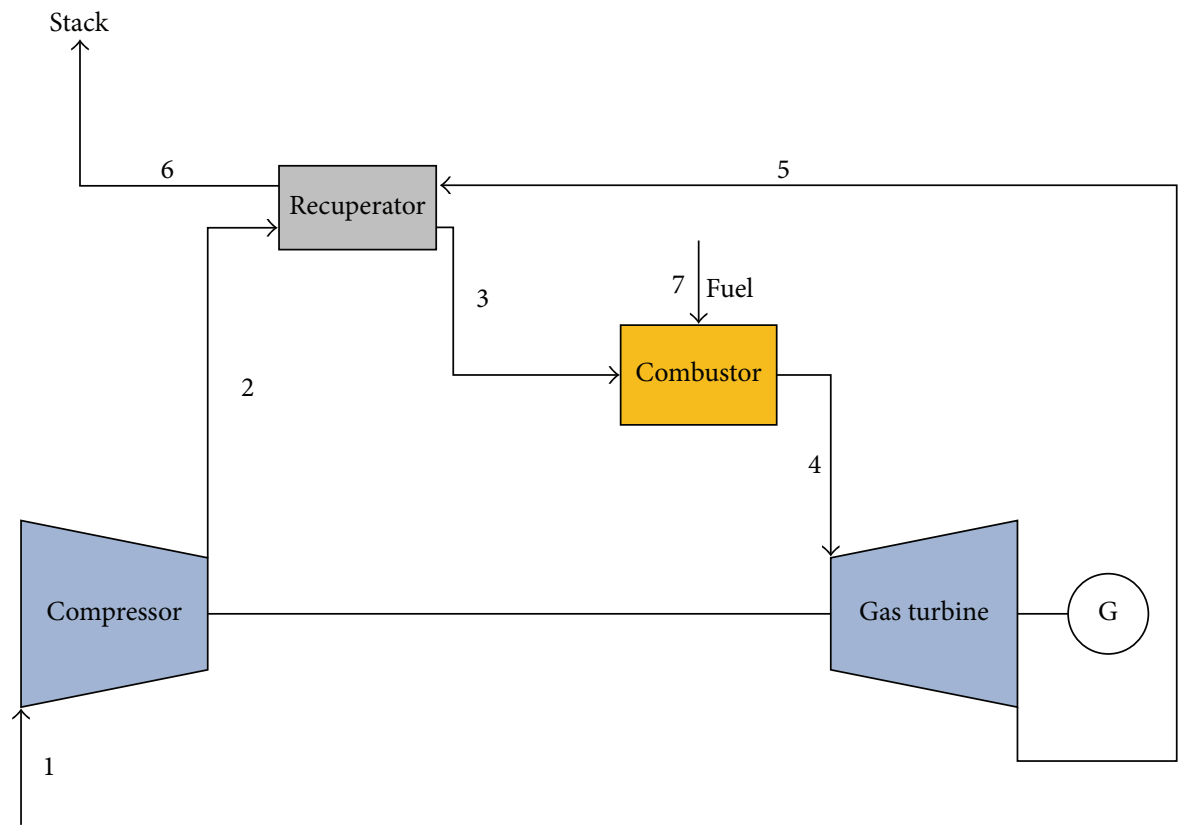

(b)

FIGURE 1: Schematic diagram of (a) GT-solar cycle and (b) GT-recuperator cycle.

And $\dot{\mathrm{Q}}_{\mathrm{rec}}$ is the heat released from irradiations into central receiver:

$$
\dot{Q}_{\text {rec }}=\eta_{\text {field }} \eta_{\text {rec }} \dot{Q}_{\text {sol,total }} \text {. }
$$

One can write

$$
\dot{Q}_{\text {sol,total }}=A * \text { DNI. }
$$

DNI is defined as direct normal irradiance which varies related to the geographical situation and a constant annual average value for a certain location is assumed.

3.3. Exergy Analysis. Exergy analysis is a powerful tool in referring exergy destructions in a power cycle while these wastes cannot be seen through energy analysis [8].
It is worth mentioning that four concepts are demonstrated in the present study. $\mathrm{Ex}_{\mathrm{F}}$ and $\mathrm{Ex}_{\mathrm{P}}$ are the fuel and product exergy rate, respectively, and also the exergy loss $\left(\mathrm{Ex}_{\mathrm{L}}\right)$ is defined as the useful exergy which is wasted to the environment with no converting to the work and exergy destruction $\left(\mathrm{Ex}_{\mathrm{D}}\right)$ due to irreversibilities.

To find the appropriate relation between these concepts, one may write

$$
\mathrm{Ex}_{\mathrm{F}}=\mathrm{Ex}_{\mathrm{P}}+\mathrm{Ex}_{\mathrm{D}} .
$$

This should be written for all components as shown schematically in Table 1 to calculate the exergy balance in each of them. Considering if the component is assumed adiabatic, the exergy loss would be zero. 
TABLE 1: Components exergy balance.

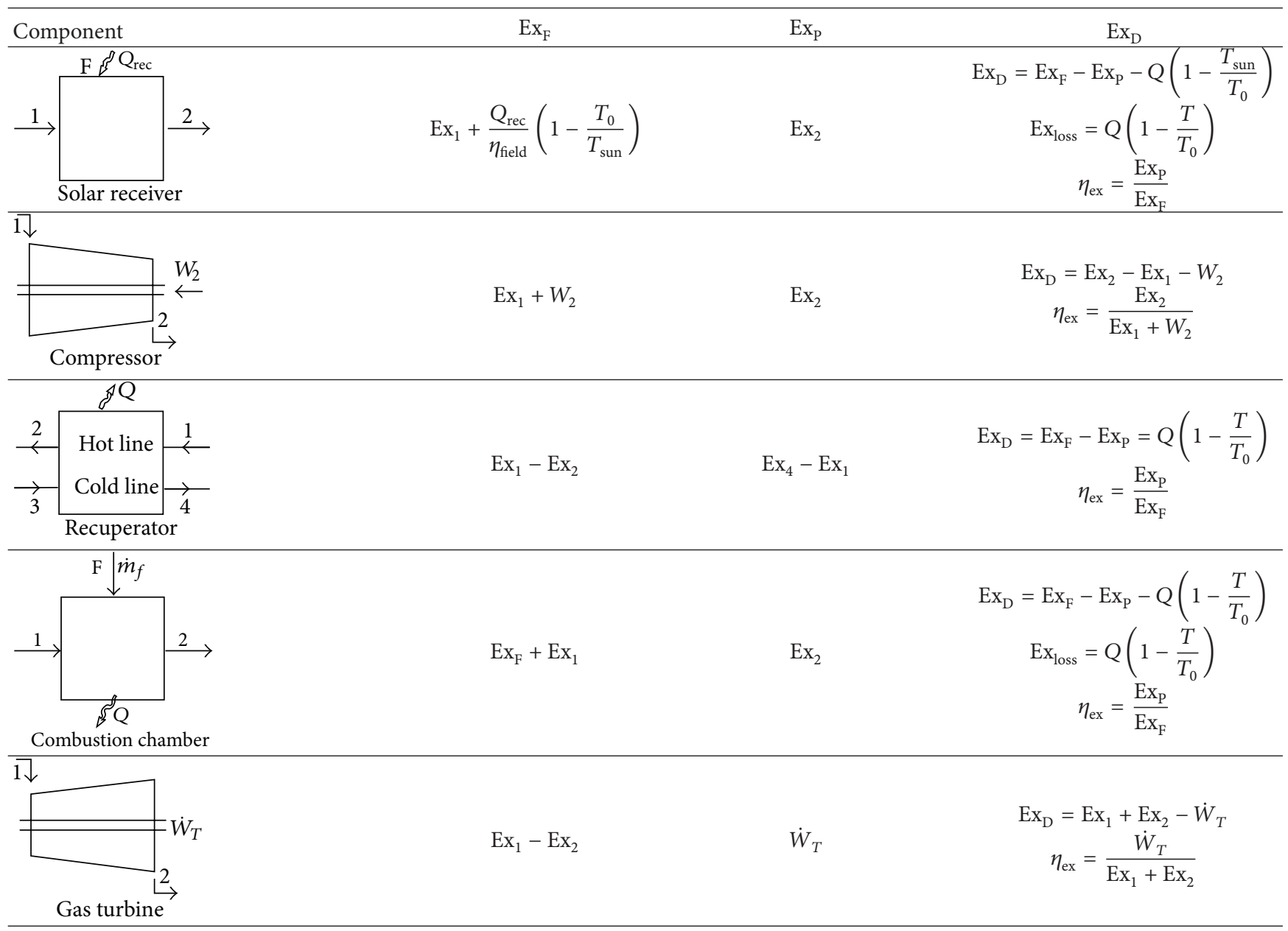

In this research study, input exergy is supplied from two different sources shown in Figure 1. The solar input exergy is defined as below:

$$
\mathrm{Ex}_{\text {sol }}=\frac{Q_{\text {rec }}}{\eta_{\text {field }}}\left(1-\frac{T_{0}}{T_{\text {sun }}}\right) .
$$

3.4. Exergoenvironmental Analysis. Although many studies in the literature are conducted based on integration methods between solar power and conventional power plants which mainly are focused on energy and exergy analysis, there is no attention to environmental issues. The present study highlights greenhouse gas emissions reduction through exergoenvironmental analysis which is conducted on both scenarios. It is considered that $\mathrm{CO}$ and $\mathrm{NO}_{x}$ are pollutant emissions in grams per kilogram. The appropriate equations for these pollutants are as follows [9]:

$$
\begin{aligned}
\dot{m}_{\mathrm{NO}_{x}} & =\frac{0.15 E 16 \tau^{0.5} \exp \left(-71100 / T_{\mathrm{pz}}\right)}{P_{3}^{0.05}\left(\Delta P_{3} / P_{3}\right)}, \\
\dot{m}_{\mathrm{CO}} & =\frac{0.179 E 99 \exp \left(7800 / T_{\mathrm{pz}}\right)}{P_{3}^{2} \tau\left(\Delta P_{3} / P_{3}\right)},
\end{aligned}
$$

where $\tau$ is the residence time in combustion zone (it is assumed constant and is equal to $0.002 \mathrm{~s}$ ), $T_{\mathrm{pz}}$ is the primary zone combustion temperature, $P_{3}$ is the combustor inlet pressure, and $\Delta P_{3} / P_{3}$ is the nondimensional pressure drop in the combustion chamber.

Accordingly $\mathrm{CO}_{2}$ is calculated as below [6]:

$$
\varepsilon=\frac{\dot{m}_{\mathrm{CO}_{2}}}{\dot{W}_{\text {net }}} .
$$

\section{Results and Discussion}

4.1. Single GT, GT-Recuperator, and GT-Solar Performance Comparison. In terms of exergy and environmental impacts, three mentioned cycles are compared. Exergy efficiency and $\mathrm{CO}_{2}$ emission for three mentioned cycles are presented in Figure 2. Exergy efficiency for the GT-solar is the least and for the recuperator is the most. It is a clear result of efficiency definition and the vast difference between solar input exergy and fuel exergy. Solar exergy due to high temperature value of its resource is much higher in comparison to fuel exergy. However, solar energy implementation reduces the natural gas consumption rate dramatically and so the emission for this cycle is about half the size of the conventional cycles. Due 


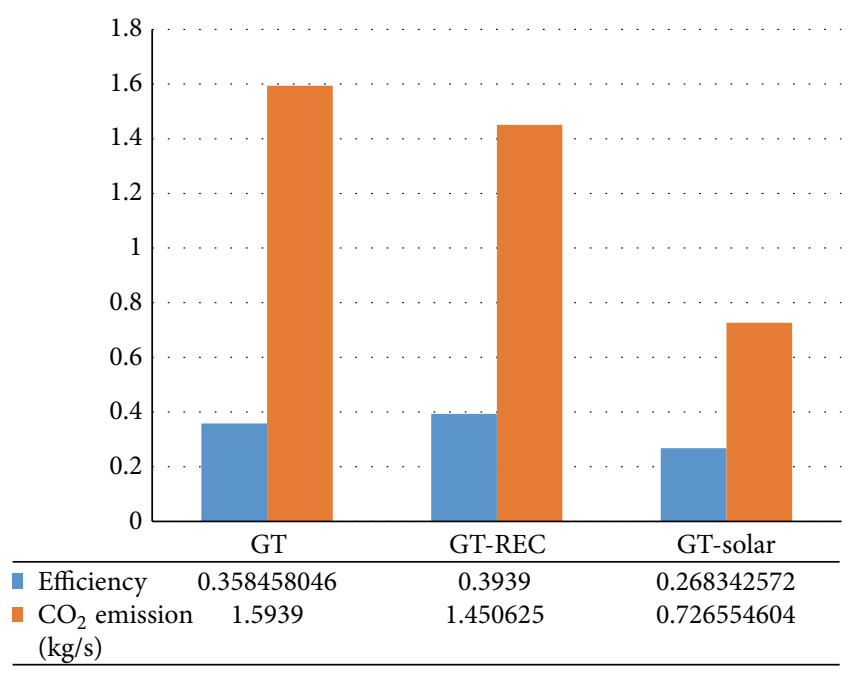

FIgURE 2: Efficiency-emission for different scenarios.

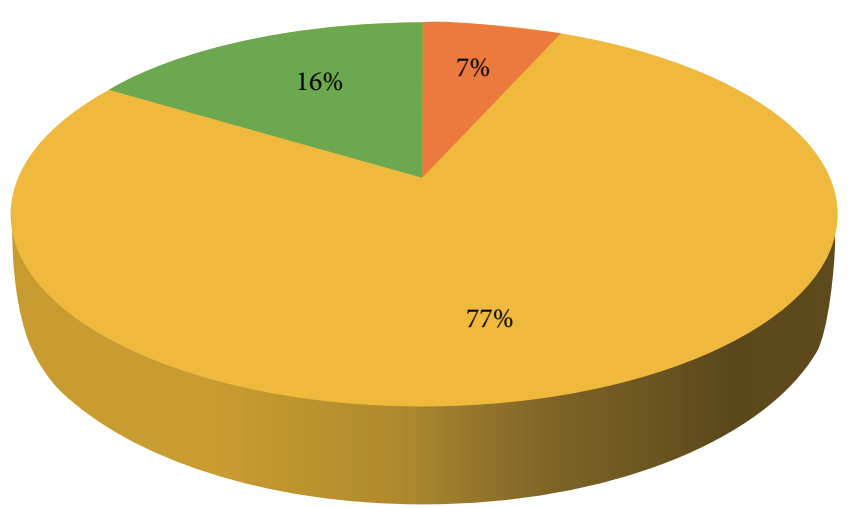

- Compressor

- Combustor

- Gas turbine

FIGURE 3: Exergy destruction distribution in GT cycle.

to higher efficiency in recuperator relative to single GT cycle, emission and fuel flow rate are lower. For cycle with single sources of exergy or energy, efficiency and $\mathrm{CO}_{2}$ emission are often correlated inversely.

Exergy flow in these three different cycles shows similar behavior. In Figure 3 exergy destruction rates in single GT are shown. As it is presented combustor is the greatest exergy destructor by 77 percent of overall destruction rate. Similarly in GT-recuperator cycle, it is also presented the same trend.

67 percent of overall exergy destruction is related to combustor in GT-recuperator. 10 percent reduction in destruction is due to higher temperature inlet to the combustor which reduced the combustion rate. If we consider the recuperator as another internal source of exergy, the overall destruction rate in cycle resources is 71 percent in GT-recuperator cycle which is shown in Figure 4.

GT-solar has shown a similar trend by 71 percent of exergy destruction in solar part (from sun to air flow) and 23 percent in combustor. In fact 94 percent of exergy destruction

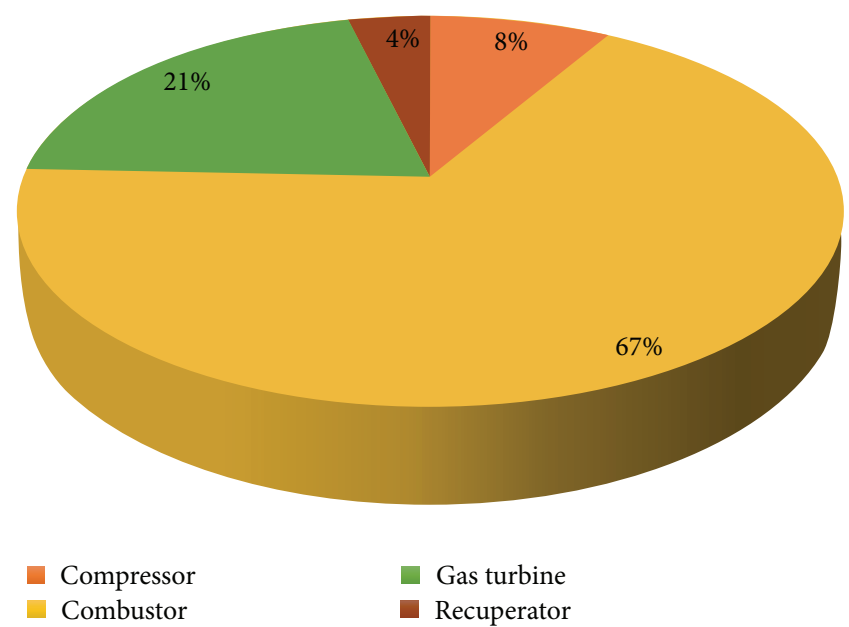

FIGURE 4: Exergy destruction distribution in GT-recuperator cycle.

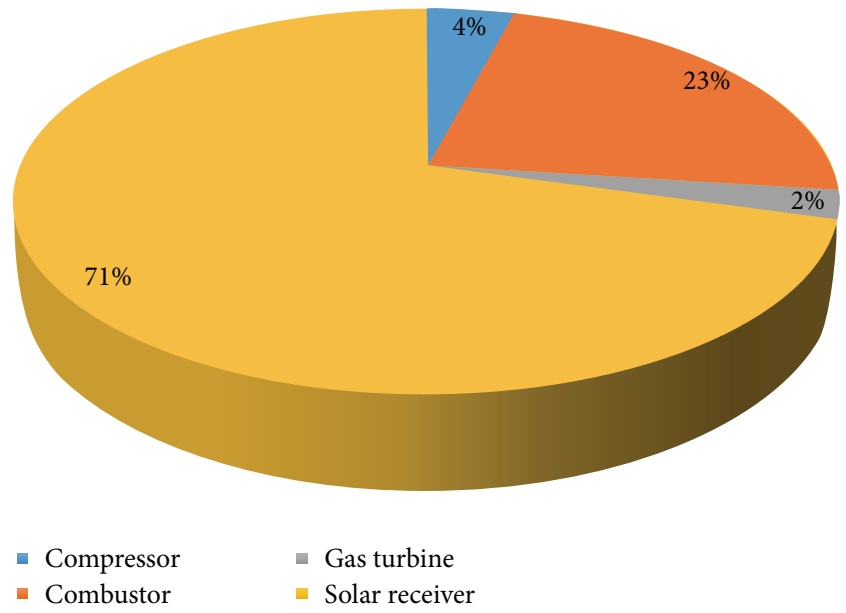

FIgURE 5: Total exergy destruction distribution in GT-solar cycle.

is related to exergy or energy resources conversion parts which has the highest value among other cycles. Figure 5 shows destruction distribution in GT-solar cycle.

Energy resources destruction percentages of total in three cycles are presented and compared in Figure 6 and show the same trend as exergy efficiency. So one may conclude that the cycle with the less exergy destruction in energy resources is the most efficient cycle.

4.2. Renewable Resources versus Nonrenewable Resources. In terms of exergy, GT-solar hybrid is the worst cycle. Exergy definition by itself does not provide an insight into the resources types.

The earth receives solar energy daily and continuously and it is absorbed, transformed, rejected, and stored in various types of energy or phenomena. On the other hand, fossil fuels are not energy resources on the plant except for human being. In fact what we are using as fossil fuels are out of the earth, usually ecology, and are the only human being impact or footprint on the environment. So any destruction 


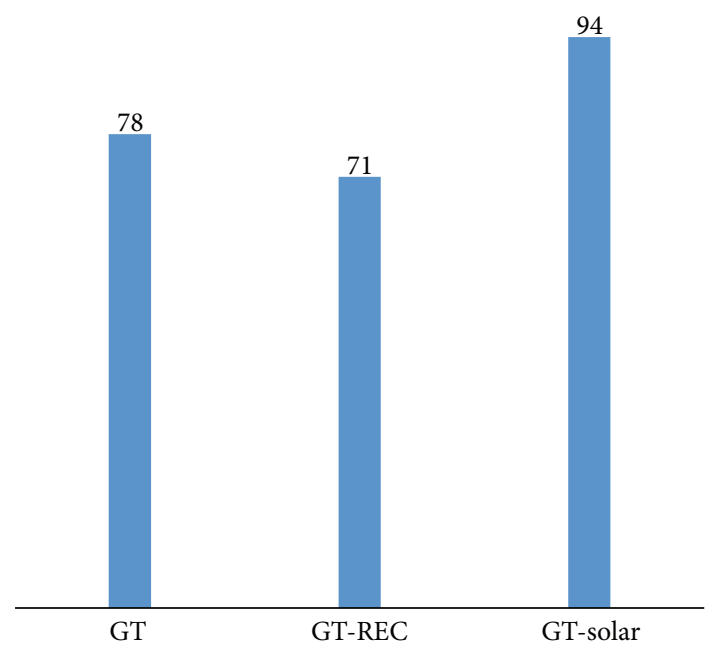

FIgURE 6: Contribution of exergy destruction in resource conversion components in different cycles.

or losses due to fossil fuels can be considered as pollution or impacts on environment.

Here, to give our resources a meaning in destruction, we define renewable and nonrenewable exergy destruction and losses. Exergy losses are important due to the fact that streams with exergy can potentially cause changes in environment because of their exergy. Both single GT and GTrecuperator cycles are purely nonrenewable. However, in GTsolar cycle sources are different. To calculate the renewable and nonrenewable exergy destruction and losses rates in GTsolar cycle, we use the following method.

Exergy comes from two different sources, sun and natural gas. We define resource distribution factor as follows:

$$
f_{\text {renewable }}=\frac{\left(\Delta \mathrm{Ex}_{\mathrm{air}}\right)_{\mathrm{rec}}}{\left(\Delta \mathrm{Ex}_{\mathrm{air}}\right)_{\mathrm{rec}}+\left(\Delta \mathrm{Ex}_{\text {flue gas }}\right)_{\text {comb }}} .
$$

Then we assume that exergy of working fluid is the algebraic combination of various resources. Now we can provide the following equations for exergy destruction and losses:

$$
\begin{aligned}
\left(\mathrm{Ex}_{\mathrm{L}}\right)_{\text {non-renwable }} & =\left(1-f_{\text {renewable }}\right)\left(\mathrm{Ex}_{\mathrm{L}}\right)_{\text {total }}, \\
\left(\mathrm{Exd}_{\mathrm{i}}\right)_{\text {non-renwable }} & =\left(1-f_{\text {renewable }_{\mathrm{i}}}\right)\left(\mathrm{Exd}_{\mathrm{i}}\right)_{\text {total }} .
\end{aligned}
$$

Furthermore, exergy destruction in solar system is considered purely renewable and destruction in combustor is considered purely nonrenewable. Implementing equations and definitions presented above, nonrenewable destruction distribution is presented in Figure 7.

Figure 8 shows the value of nonrenewable destruction and losses in different cycles. Implementing nonrenewable losses and destructions, the main advantage of the GT-solar cycle is quantitatively measured. Nonrenewable losses which are impacts of human beings activities on environment have their least value in GT-solar cycle.

GT-solar cycle parameters are summarized in Table 2. In this table, parameters like solar share, exergy inputs,

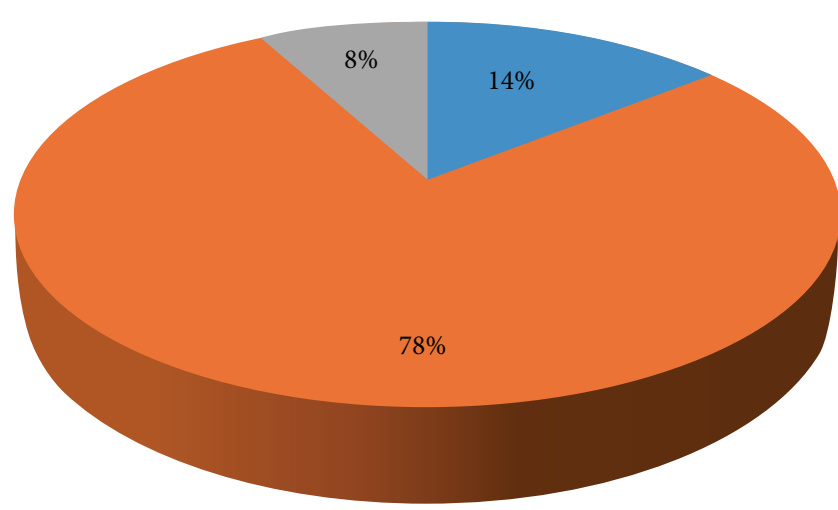

- Compressor

- Combustor

- Gas turbine

FIGURE 7: Nonrenewable exergy destruction distribution in GTsolar cycle $(\mathrm{kW})$.

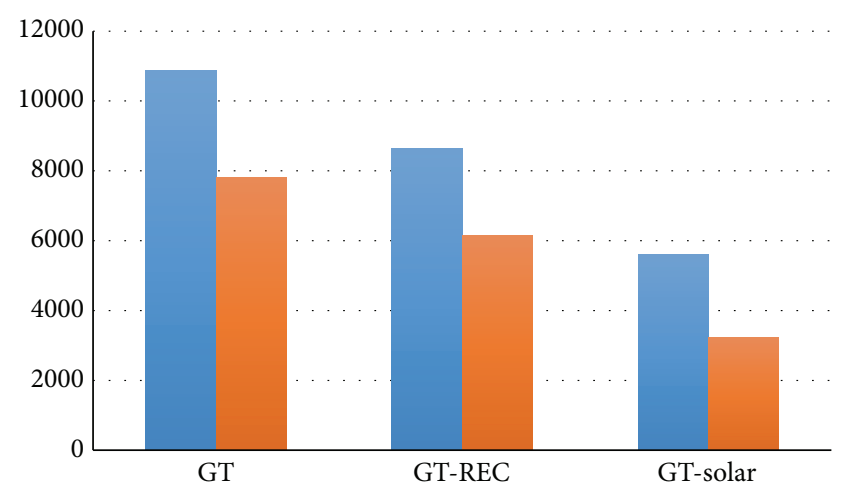

- Nonrenewable exergy destruction (kW)

- Nonrenewable exergy loss (kW)

FIGURE 8: Nonrenewable exergy destruction and losses in different cycles.

efficiency, and destruction of different components are presented. Data are assumed based on project SOLGATE [4].

In addition to mentioned analysis, $\mathrm{NO}_{x}$ and $\mathrm{CO}$ emission are predicted for different cycles. Results are tabulated in Table 3. Due to lowest fuel flow rate in GT-solar cycle, emissions are lowest values. $\mathrm{NO}_{x}$ in GT-recuperator is higher than GT cycle because of higher combustor inlet temperature. $\mathrm{CO}$ emission shows an opposite trend.

\section{Conclusions}

Different cycles are presented and compared according to exergy and environmental analyzing tools. Although GTsolar cycle is the worst according to exergy analysis, its main advantages over other conventional cycles is highlighted when resource valued exergy analysis is used.

In addition, the above analysis shows that resource conversion processes are the most destructive ones in the cycle. Furthermore, the cycle exergy efficiency is directly correlated to resource destruction contribution in the cycle. 
TABle 2: Performance parameters of GT-solar cycle.

\begin{tabular}{|c|c|}
\hline Parameter & Value \\
\hline Pressure ratio & 14 \\
\hline $\operatorname{TIT}\left({ }^{\circ} \mathrm{C}\right)$ & 1080 \\
\hline$\eta_{\text {comp }}(\%)$ & 0.835 \\
\hline$\eta_{\mathrm{GT}}(\%)$ & 0.93 \\
\hline Combustor inlet temperature $\left({ }^{\circ} \mathrm{C}\right)$ & 800 \\
\hline Receiver efficiency (\%) & 0.94 \\
\hline Field efficiency $(\%)$ & 0.55 \\
\hline Receiver pressure drop & 0.03 \\
\hline$\eta_{\text {recup }}(\%)$ & 0.97 \\
\hline \multicolumn{2}{|c|}{ Exergy efficiencies } \\
\hline Compressor (\%) & 0.93 \\
\hline Combustor (\%) & 0.86 \\
\hline Gas turbine (\%) & 0.97 \\
\hline Receiver (\%) & 0.41 \\
\hline \multicolumn{2}{|c|}{ Exergy destruction rates } \\
\hline Compressor (kW) & 908.53 \\
\hline Combustor (kW) & 4973.28 \\
\hline Gas turbine $(\mathrm{kW})$ & 504.89 \\
\hline Receiver $(\mathrm{kW})$ & 15374.38 \\
\hline \multicolumn{2}{|c|}{ Overall cycle parameters } \\
\hline Solar share (\%) & 0.56 \\
\hline$f_{\text {renewable }}$ & .557 \\
\hline Total exergy loss (kW) & 7310 \\
\hline Total exergy efficiency (\%) & 0.268 \\
\hline Total exergy destruction $(\mathrm{kW})$ & 21761.09 \\
\hline Solar input exergy $(\mathrm{kW})$ & 26200 \\
\hline Fuel flow rate $(\mathrm{kg} / \mathrm{s})$ & 0.264 \\
\hline Air flow rate $(\mathrm{kg} / \mathrm{s})$ & 33.63 \\
\hline Predicted $\mathrm{NO}_{x}$ emission $(\mathrm{kg} / \mathrm{s})$ & $1.27 E-10$ \\
\hline Predicted CO emission $(\mathrm{kg} / \mathrm{s})$ & 0.0108 \\
\hline \multicolumn{2}{|c|}{ TABLE 3: $\mathrm{NO}_{x}$ and CO emissions. } \\
\hline $\mathrm{NO}_{x}(\mathrm{~kg} / \mathrm{s})$ & $\mathrm{CO}(\mathrm{kg} / \mathrm{s})$ \\
\hline $3.5478 E-10$ & 0.02 \\
\hline $3.7395 E-10$ & 0.0179 \\
\hline $1.2663 E-10$ & 0.0108 \\
\hline
\end{tabular}

Total exergy destruction in GT-solar cycle is higher than other cycles. However, nonrenewable destruction is the lowest for GT-solar among different scenarios. As nonrenewable destructions and losses have significant impacts on the environment, the best advantage of renewable resources and hybrid GT-solar cycle is minimizing the impacts on the environment. $\mathrm{NO}_{x}, \mathrm{CO}$, and $\mathrm{CO}_{2}$ emissions are also reduced significantly by using solar hybrid cycle.

\section{Nomenclature}

\section{A: $\quad$ Area, $\mathrm{m}^{2}$}

DNI: Direct normal irradiance, $\mathrm{W} / \mathrm{m}^{2}$

ex: Specific exergy, kJ/kg
Ex: $\quad$ Exergy, kJ

Exd: $\quad$ Exergy destruction, $\mathrm{kJ}$

$f: \quad$ Resource distribution factor

GT-REC: Gas turbine cycle with recuperator

GT-SOL: Gas turbine cycle with solar receiver

$h: \quad$ Specific enthalpy, $\mathrm{kJ} / \mathrm{kg}$

LHV: $\quad$ Lower heating value, $\mathrm{kJ} / \mathrm{kg}$

$\dot{m}: \quad$ Mass flow rate, $\mathrm{kg} / \mathrm{h}$

$P: \quad$ Pressure, bar

Q: $\quad$ Heat transfer, $\mathrm{kJ} / \mathrm{kg}$

$s$ : $\quad$ Specific entropy, $\mathrm{kJ} / \mathrm{kgK}$

TIT: $\quad$ Turbine inlet temperature, ${ }^{\circ} \mathrm{C}$

T: $\quad$ Temperature, ${ }^{\circ} \mathrm{C}$.

\section{Greek Letters}

$\varepsilon: \quad \mathrm{CO}_{2}$ emission per net output power, $\mathrm{kg}_{\mathrm{CO}_{2}} / \mathrm{MWh}$

$\eta: \quad$ Efficiency

$\eta_{\text {field }}$ : Heliostat field efficiency

$\eta_{\text {rec }}$ : Receiver efficiency.

Subscripts

0: $\quad$ Dead state

comb: Combustor

comp: Compressor

D: Destruction

F: Fuel

GT: Gas turbine

i: $\quad$ Index

in: Inlet

L: Loss

out: Outlet

P: Product

rec: Receiver

recup: Recuperator

sol: Solar.

\section{Competing Interests}

The authors declare that they have no competing interests.

\section{References}

[1] M. S. Jamel, A. Abd Rahman, and A. H. Shamsuddin, "Advances in the integration of solar thermal energy with conventional and non-conventional power plants," Renewable and Sustainable Energy Reviews, vol. 20, pp. 71-81, 2013.

[2] C. Xu, Z. Wang, X. Li, and F. Sun, "Energy and exergy analysis of solar power tower plants," Applied Thermal Engineering, vol. 31, no. 17-18, pp. 3904-3913, 2011.

[3] O. Behar, A. Khellaf, and K. Mohammedi, "A review of studies on central receiver solar thermal power plants," Renewable and Sustainable Energy Reviews, vol. 23, pp. 12-39, 2013.

[4] P. Schwarzbözl, R. Buck, C. Sugarmen et al., "Solar gas turbine systems: design, cost and perspectives," Solar Energy, vol. 80, no. 10, pp. 1231-1240, 2006.

[5] P. Ahmadi and I. Dincer, "Thermodynamic and exergoenvironmental analyses, and multi-objective optimization of a gas 
turbine power plant," Applied Thermal Engineering, vol. 31, no. 14-15, pp. 2529-2540, 2011.

[6] P. Ahmadi, H. Barzegar Avval, A. R. Ghaffarizadeh, and M. H. Saidi, "Thermo-economic-environmental multiobjective optimization of a gas turbine power plant with preheater using evolutionary algorithm," International Journal of Energy Research, vol. 35, no. 5, pp. 389-403, 2011.

[7] P. Heller, M. Pfänder, T. Denk et al., "Test and evaluation of a solar powered gas turbine system," Solar Energy, vol. 80, no. 10, pp. 1225-1230, 2006.

[8] I. Dincer and M. A. Rosen, Energy, Environment and Sustainable Development, Elsevier, Amsterdam, The Netherlands, 2007.

[9] N. K. Rizk and H. C. Mongia, "Semianalytical correlations for NOx, CO, and UHC emissions," Journal of Engineering for Gas Turbines and Power, vol. 115, no. 3, pp. 612-619, 1993. 


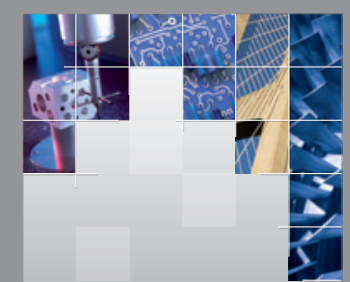

\section{Enfincering}
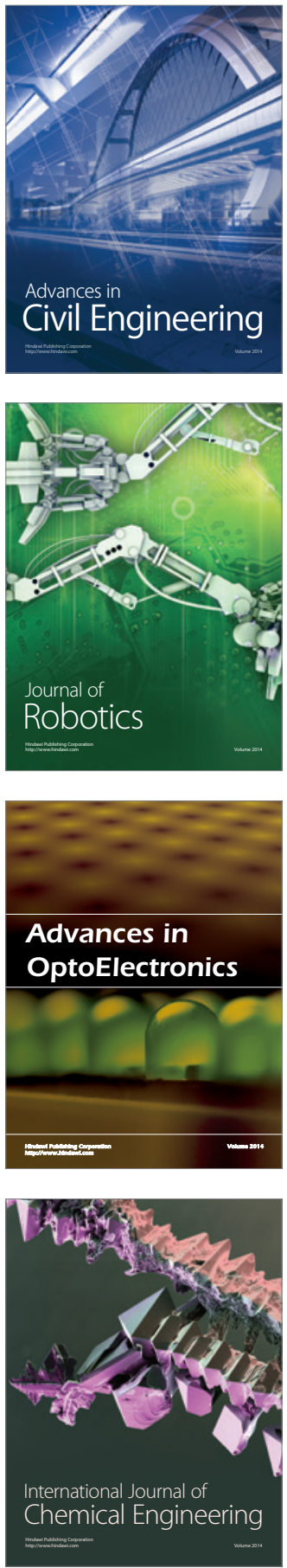

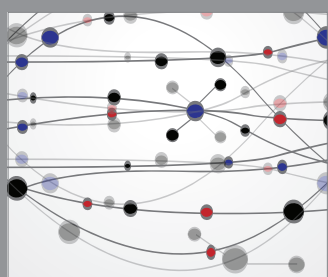

The Scientific World Journal

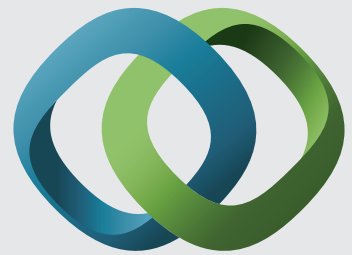

\section{Hindawi}

Submit your manuscripts at

http://www.hindawi.com
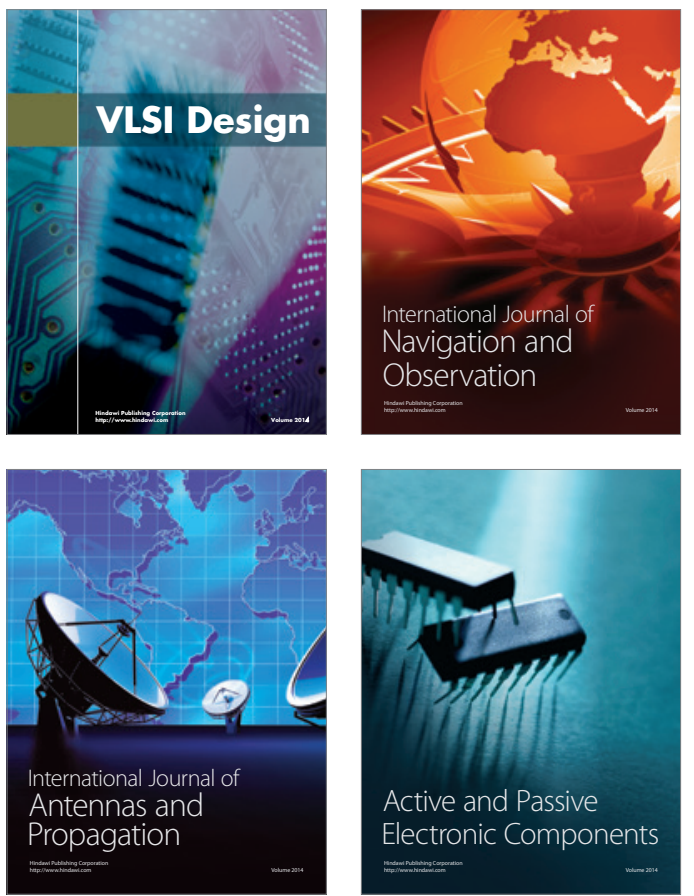
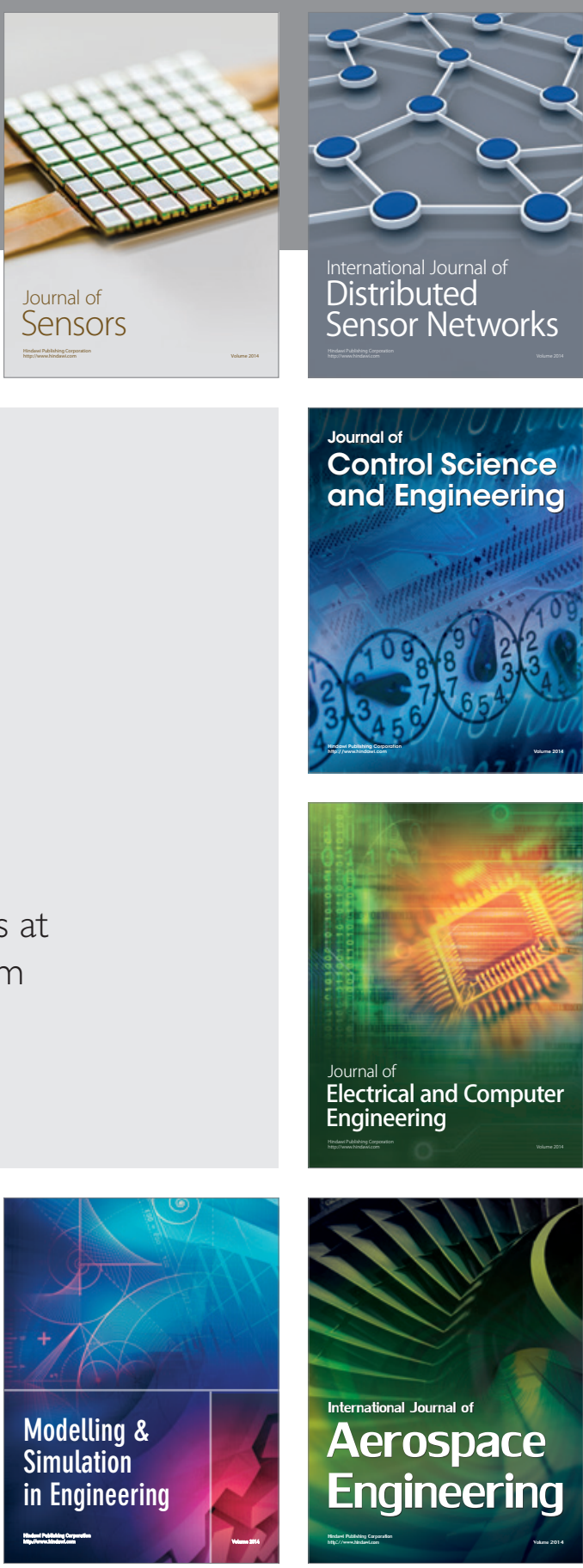

International Journal of

Distributed

Sensor Networks

Journal of

Control Science

and Engineering
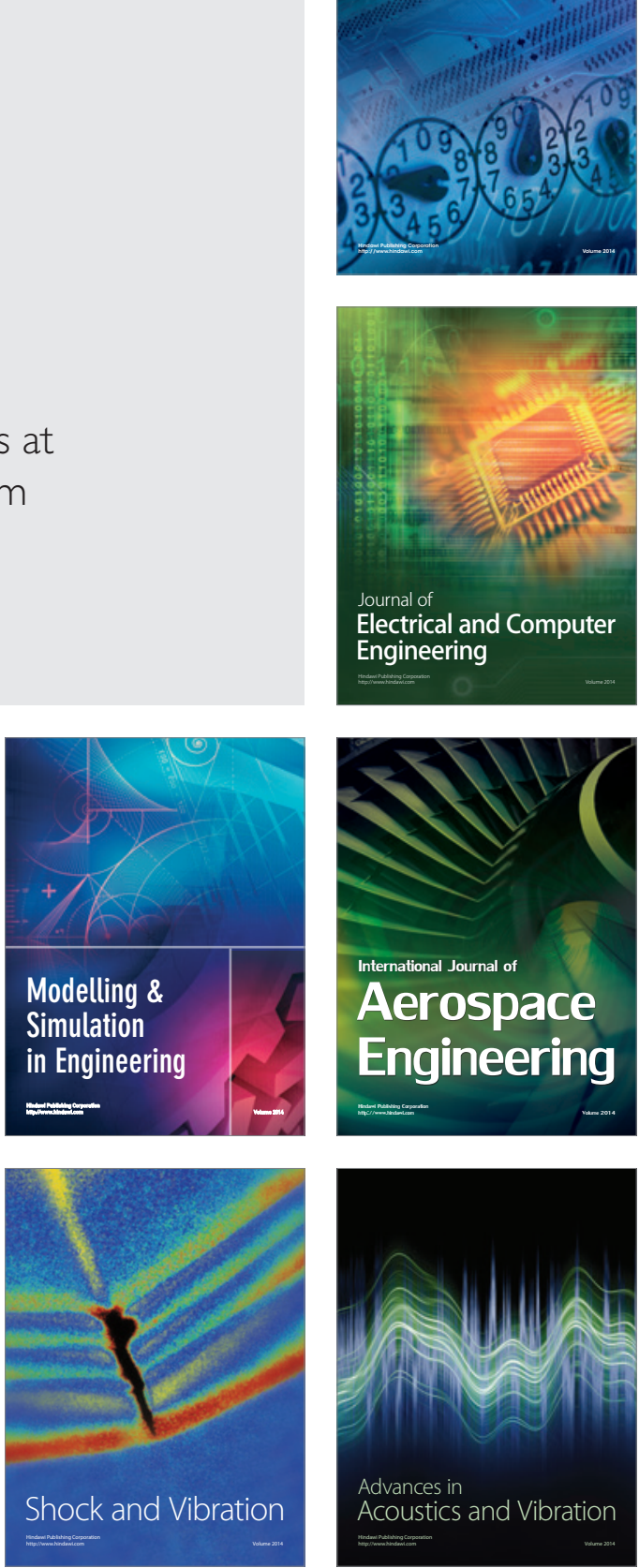